\title{
Strengthening Mechanisms in the Surface Layer of Duralumin Modified by a High Current Pulsed Relativistic Electron Beam
}

\author{
V.V. Bryukhovetsky1,, , V.V. Lytvynenko, D.E. Myla1, Yu.F. Lonin², A.G. Ponomarev², V.T. Uvarov² \\ ${ }^{1}$ Institute of Electrophysics and Radiation Technologies NAS of Ukraine, p.o. box. 8812, 28, Chernyshevsky St., \\ 61002 Kharkiv, Ukraine \\ ${ }^{2}$ NSC «Kharkiv Institute of Physics and Technology» NAS of Ukraine, 1, Akademichna St., 61108 Kharkiv, Ukraine
}

(Received 24 November 2021; revised manuscript received 09 December 2021; published online 20 December 2021)

\begin{abstract}
The mechanisms of strengthening of the surface layer of D16AT aluminum alloy irradiated with a high-current relativistic electron beam were studied. The alloy was irradiated with an electron beam with a particle energy of $0.35 \mathrm{MeV}$, a beam current of $2.0 \mathrm{kA}$, and a pulse duration of $5 \mu \mathrm{s}$. This article shows that the processing of D16AT aluminum alloy by a high-current relativistic electron beam leads to melting of irradiated surface and the formation of a surface layer with a modified structural-phase state. The thickness of this layer is approximately $100 \mu \mathrm{m}$. A solid solution based on aluminum is the main constituent of this layer. At the same time, intermetallic phases that were present in the initial state of the alloy cannot be detected by means of X-ray diffractometry. It was established that processing of the surface of D16AT alloy with a pulsed electron beam leads to grain refining. In the initial state of the alloy, the average grain size is $11 \mu \mathrm{m}$. In the modified layer, the average grain size is approximately $0.8 \mu \mathrm{m}$. The microhardness of the irradiated layer increases by almost $50 \%$. The contribution of different strengthening mechanisms to the change of strength characteristics of the modified surface layer was analyzed. It was shown that the dispersion mechanism makes the main contribution to the strengthening of the alloy in the initial state. While the dislocation mechanism of strengthening plays a key role in increasing the microhardness of the irradiated layer. The importance of these observations for thermomechanical processing of aluminum alloys in order to further improve their strength characteristics was discussed.
\end{abstract}

Keywords: High current electron beam, Aluminum alloy, Microhardness, Strengthening mechanisms.

DOI: 10.21272/jnep.13(6).06025

PACS numbers: 07.05.Tp, 61.80.Fe, 87.63.Hg

\section{INTRODUCTION}

The energy flux density technique is widely used in the surface treatment of structural materials. The effect of intense pulsed electron beams on the material serves as an example of such a technique [1-5]. The implement of high current relativistic electron beams can improve the surface layer properties and achieve better values than when using conventional treatment techniques. It is about pulse energy transfer from a charged particle beam to the treated surface, including the irradiation way and ability to pass through structural and phase transformations. The irradiation energy at the time of pulse activity is almost completely absorbed by the material layer, the thickness of which is equal to the electron path length, and is converted into heat energy. The only exception is bremsstrahlung. We have to concern the peculiarities of heating by electron beams, e.g., the absorbed energy is distributed through the irradiated layer unevenly, penetrating no more than $1 / 3$ of the electron path length. If there is enough absorbed energy to melt the target compound, we can observe the maximum variety of processes. Herewith, during impulse activity and a little bit later, there are processes of ejection of the molten compound from the surface, melting of the target beyond the electron path length, crystallization of the molten part, and solid phase transformation. As a result, the structure and properties of the surface layer change. Thus, we can obtain better hardness, corrosion resistance and dynamic tensile strength of the item [1]. The molten layer thickness depends on both the particle energy and irradiated specimen density. Microsecond intense pulsed electron beams with a high-current density of up to $10^{9} \mathrm{~W} / \mathrm{cm}^{2}$ and particles with energies exceeding $0.3 \mathrm{MeV}$ are able to heat and melt fairly evenly the upper surface layer of the aluminum alloy to a depth of about 100 microns [2, 3]. Due to this treatment method, it is possible to localize the modification of the upper surface layer of items.

At the same time, the establishment of correlation between the composition, structure and properties of metallic materials is the most important task of metal science. However, despite the vast accumulated experimental material distinguished the correlation between the item structure and properties, this issue is subject to further research, as well as the mechanisms responsible for the hardness of aluminum alloys of the $\mathrm{Al}-\mathrm{Cu}-$ $\mathrm{Mg}$ system, despite the growing number of works devoted to thermal hardening of these items [6, 7]. The paper studies D16AT aluminum alloy, which belongs to the wrought aluminum alloy brand. Investigation of the strengthening mechanism after intense pulsed electron beams is important to recognize the cause of structural and phase transformations, leading to better hardness of aluminum alloys.

\section{EXPERIMENTAL PROCEDURE}

Irradiation of alloy sheets was performed with a high current pulsed beam of relativistic electrons at the TEMP-A accelerator in the NSC KIPT NAS of Ukraine 
$[2,3]$. The energy flux density on the target $W$ was approximately $10^{9} \mathrm{~W} / \mathrm{cm}^{2}$ (beam energy $E \sim 0.35 \mathrm{MeV}$, current $I \sim 2000 \mathrm{~A}$, pulse duration $\tau_{i} \sim 5 \cdot 10^{-6} \mathrm{~s}$, beam diameter $D \sim 3 \mathrm{~cm}$ ).

Mechanical properties at room temperature were obtained from static tensile tests of the alloy, and the Keller's reagent $\left(1 \% \mathrm{HF}, 1.5 \% \mathrm{HCl}, 2.5 \% \mathrm{HNO}_{3}, 95 \%\right.$ $\mathrm{H}_{2} \mathrm{O}(\mathrm{ml})$ ) revealed the grain microstructure on the polished etched surface. The grain microstructure research was carried out using a TESCAN VEGA3 LMH scanning electron microscope (SEM) and an MIM-10 optical microscope. A PMT-3M microhardness tester was used to confirm the microhardness changes. The Vickers microhardness $(H V)$ was found by applying a force of $50 \mathrm{~g}$ with the help of an indenter for dwell time of $25 \mathrm{~s}$ with a microhardness tolerance of $10 \%$. The microhardness was defined by the equation

$$
H V=\frac{1,854 P}{R^{2}},
$$

where $P$ is the load, $R$ is the length of the diagonals of a square indentation measured in two mutually perpendicular directions.

X-ray structure analysis was carried out on a DRON 4-07 diffractometer with $\mathrm{CuK}_{\alpha}$ radiation at a current of $30 \mathrm{~mA}$ and a voltage of $40 \mathrm{kV}$. The lattice parameter and the dislocation density were evaluated using X-ray diffraction (XRD) line-profile analysis according to the Rietveld method. Energy dispersive X-ray spectroscopy (EDS) giving the spatial distribution of alloy elements was done by applying a TESCAN VEGA3 LMH SEM equipped with an EDS Bruker XFlash 5010 detector.

\section{RESULTS}

The paper focuses mainly on examining D16AT aluminum alloy (comparable to 1160 aluminum alloy). D16AT aluminum alloy of the $\mathrm{Al}-\mathrm{Cu}-\mathrm{Mg}$ system is able to compete in hardness against some steel grades, but it has a much lower specific gravity [9]. Table 1 shows the complete chemical composition of D16AT aluminum alloy.

Table 1 - Chemical composition (wt. \%) of D16AT aluminum alloy

\begin{tabular}{lccccccc}
\hline $\mathrm{Al}$ & $\mathrm{Cu}$ & $\mathrm{Mg}$ & $\mathrm{Mn}$ & $\mathrm{Si}$ & $\mathrm{Fe}$ & $\mathrm{Zn}$ & $\mathrm{Ti}$ \\
Bal. & 4.38 & 1.37 & 0.73 & 0.35 & 0.35 & 0.16 & 0.05 \\
\hline
\end{tabular}

A specimen for research irradiation with a thickness of $4 \mathrm{~mm}$ was cut from a sheet of D16AT aluminum alloy. Sheet products made of D16AT aluminum alloy are cladded and undergo quenching and natural aging. Before being irradiated, the cladding layer was ground away, and the specimen surface was polished. Fig. 1 shows the microstructure of D16AT aluminum alloy. The grain structure is obviously completely recrystallizing. It is mostly equiaxial grain structure with slight grain inhomogeneity. The average grain size is $11 \mu \mathrm{m}$.

Mechanical testing of the specimens made of sheet products with applying a tensile strength testing machine at room temperature showed a tensile limit equal to $425 \mathrm{MPa}$ and $\sigma_{0.2}=312 \mathrm{MPa}$. The maximum tensile strength of the target specimen at room temperature was $16 \%$.

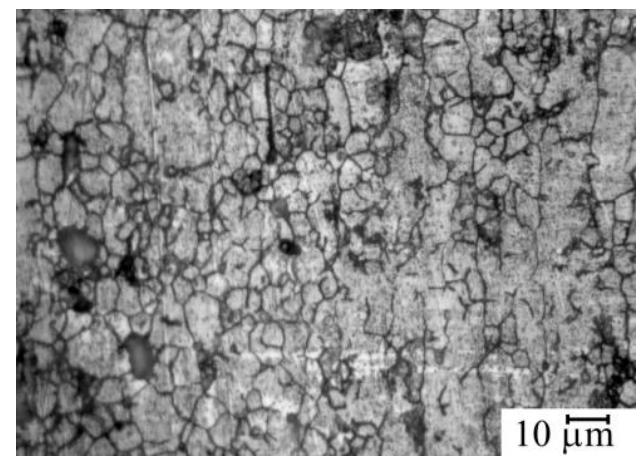

Fig. 1 - The microstructure of D16AT aluminum alloy
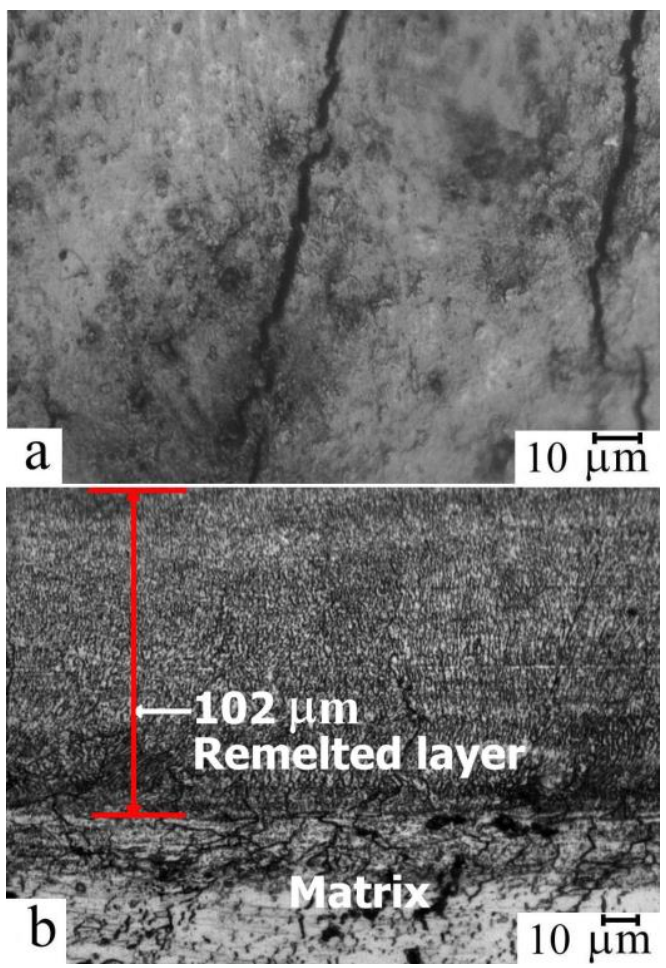

Fig. 2 - View of the irradiated surface of D16AT aluminum alloy (a); view of the cross-section of D16AT alloy in the electron beam treatment zone (b)

Fig. 2 shows the surface of D16AT aluminum alloy after relativistic electron beam irradiation and the view of the cross-sectional cut in the electron beam treatment zone. Intensive specimen heating generated by a pulsed electron beam melted partially its surface layer. The solidification of the melted layer in a wide range of temperatures and at high pressure caused directed crystallization of the melt under nonequilibrium conditions and resulted in nanocrystalline and amorphous structures [1-5]. At spatial beam intensities exceeding $10^{7} \mathrm{~J} / \mathrm{cm}^{2}$, the pressure inside the target can achieve several megabars. Since the surface zone absorbs the maximum of the beam energy, a surface microexplosion occurs, which is accompanied by a shock-plastic wave, propagating towards the target, and the material emission towards the beam activity. The melted layer of the target material crystallizes due to heat exchange with the unmelted area. The mentioned above effects form a remelted layer, serving as a modified one, on the specimen surface of D16AT aluminum alloy. Fig. 2a shows 
that the surface of the remelted layer is covered with a population of cracks. The thickness of the remelted layer is on average about $100 \mu \mathrm{m}$ (Fig. 2b). It was established that the surface treatment of D16AT aluminum alloy by a pulsed electron beam reduces average grain size up to $0.8 \mu \mathrm{m}$ in the remelted layer. The structure of the modified layer is considered nonequilibrium due to the blurred outlines of grain boundaries.

D16AT aluminum alloy can contain phase particles in equilibrium with the aluminum matrix at room temperature: $S$-phases $\left(\mathrm{Al}_{2} \mathrm{CuMg}\right), \theta$-phases $\left(\mathrm{Al}_{2} \mathrm{Cu}\right)$, $\mathrm{Al}_{6}(\mathrm{CuFeMn}), \mathrm{Al}_{15} \mathrm{Si}_{2}(\mathrm{CuFeMn})_{3}$ and $\left(\mathrm{Al}_{20} \mathrm{Cu}_{2} \mathrm{Mn}_{3}\right)$. The phase composition of the target alloy in its state and its surface layer after irradiation was established by X-ray testing. Fig. 3 shows the X-ray image of the initial specimen of D16AT aluminum alloy with intense diffraction peaks meeting the aluminum-based solid solution ( $\alpha_{\mathrm{Al}}$-phase). The microstructure of as-cast D16AT aluminum alloy shows the presence of diffraction peaks of $\theta$ - and $S$-phases. Fig. 3b shows the X-ray diffractogram of the D16AT aluminum alloy surface layer remelted by a pulsed electron beam, with intense diffraction peaks meeting the aluminum-based solid solution ( $\alpha$ Al-phase), but the X-ray diffractogram of the remelted layer shows no peaks meeting $\theta$ - and $S$-phases. This speaks about hardly possible minimal presence of phases in the remelted layer. Fig. 3 compares the X-ray diffractograms and shows that irradiation is the reason for the redistribution of the orientation of $a$-crystallites of aluminum-based solid solution due to the change in the intensity ratio of $\alpha_{\mathrm{Al}}$-phase diffraction peaks.

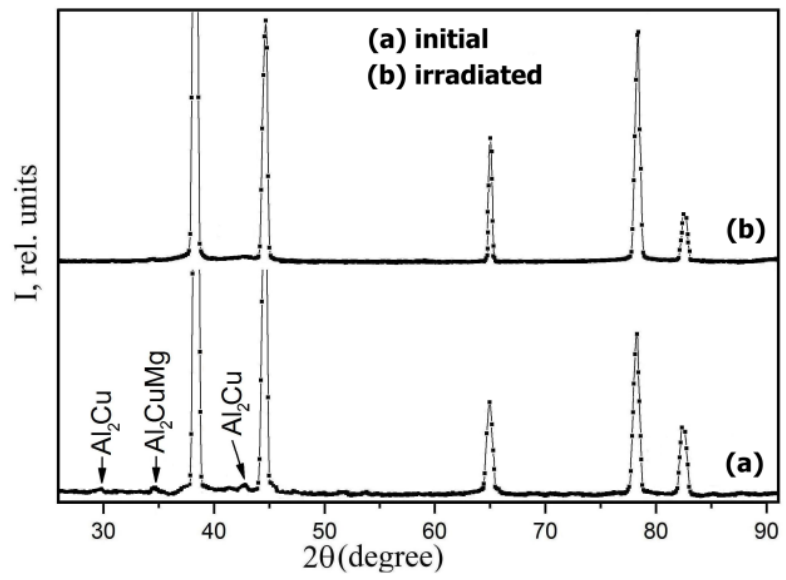

Fig. 3 - X-ray image of the initial D16AT aluminum alloy specimen (a) and the real X-ray image of the remelted surface layer irradiated with an electron beam (b)

It is important to consider the irradiation temperature of the remelted layer over $1000 \mathrm{~K}$ for proper recognition of the phase compound changing processes occurring in the modified layer of D16AT aluminum alloy [3]. The melting temperature of the $S$-phase reached $500{ }^{\circ} \mathrm{C}$ and $591{ }^{\circ} \mathrm{C}$ for the $\theta$-phase. So, both phases are present in as-cast D16AT aluminum alloy and require a lower melting temperature than the one under irradiation of the surface layer with a pulsed electron beam. The electron beam affects the treatment zone with the accompanied emerged high pressure crashing the various structural elements there. Irradiation of D16AT aluminum alloy meets these conditions, so available in the alloy phases will be crashed, partially melted and dissolved. High cooling rates of the melt at $10^{4}-10^{6} \mathrm{~K} / \mathrm{s}$ exceed dramatically the critical cooling rates preventing phase segregation in the aluminum matrix. Therefore, the remelted layer may involve a hardening phase, but very small in size with an equal distribution along with the modified layer.

Irradiation of D16AT aluminum alloy with a pulsed electron beam increases the dislocation density of the modified layer. In compliance with the data of X-ray structure analysis, the dislocation density of the as-cast alloy specimen is $0.7 \times 10^{14} \mathrm{~m}^{-2}$ and of the irradiated layer is $5.9 \times 10^{14} \mathrm{~m}^{-2}$. So, the dislocation density of the modified layer increases dramatically.

The lattice parameter of the aluminum-based solid solution is $0.4051 \mathrm{~nm}$ in the as-cast specimen of D16AT aluminum alloy and $0.4049 \mathrm{~nm}$ in the modified remelted layer, e.g., the treated surface layer comes with the lattice parameter decrease. To recognize the reason for the lattice parameter change, we have to consider the following: melting and dissolution during irradiation of strengthening phases should increase the amount of alloying elements. EDS distinguishes that the aluminum-based solid solution of the as-cast alloy contains approximately 0.4 wt. $\% \mathrm{Cu}$, a close value to limit solubility of copper at $20^{\circ} \mathrm{C}$, and 0.3 wt. $\% \mathrm{Mg}$. The copper concentration in the remelted layer of the aluminumbased solid solution increases up to $3.1 \mathrm{wt} \%$, and magnesium - to 0.9 wt. \%. The magnesium concentration increases in the aluminum matrix (the atomic radius of $\mathrm{Mg}$ is greater than that of $\mathrm{Al}$ ) leads to an increase in the lattice parameter. The lattice parameter increases due to the possible presence of an excessive concentration of quenched vacancies [8]. However, the concentration of copper in the modified layer is significantly higher than its limited solubility at $20^{\circ} \mathrm{C}$, indicating the formation of a supersaturated solid solution of copper in aluminum. It is the reason for alloy lattice parameter decrease (the atomic radius of $\mathrm{Cu}$ is less than that of $\mathrm{Al}$ ). A decrease in the grain size to nanocrystalline one leads to an increase in the fraction of grain boundaries. This, according to [9], should also lead to a decrease in the lattice parameter. Thus, the factors affecting the decrease in the lattice parameter are more significant than the ones causing the increase in the lattice parameter.

Structural-phase transformations in the surface layer under the action of a pulsed electron beam should cause changes in hardening properties. Fig. 4 shows the distribution of microhardness values over the crosssection of D16AT aluminum alloy from the side affected by a pulsed electron beam. The microhardness of the alloy is $101 H V_{0.05}$. Fig. 4 shows a dramatic increase in the microhardness of D16AT aluminum alloy, modified by irradiation, with an average value within $147 H V_{0.05}$. Thus, the pulsed electron beam performance improves the hardening of the surface layer of D16AT aluminum alloy as twice as of the as-cast one. The microhardness values go beyond the boundaries of the remelted layer affected by the electron beam. However, these microhardness values are still higher than the ones for the as-cast specimen. The values of the modified layer meet the ones of the as-cast specimen only at a distance of $200 \mu \mathrm{m}$ deeper from the surface. 


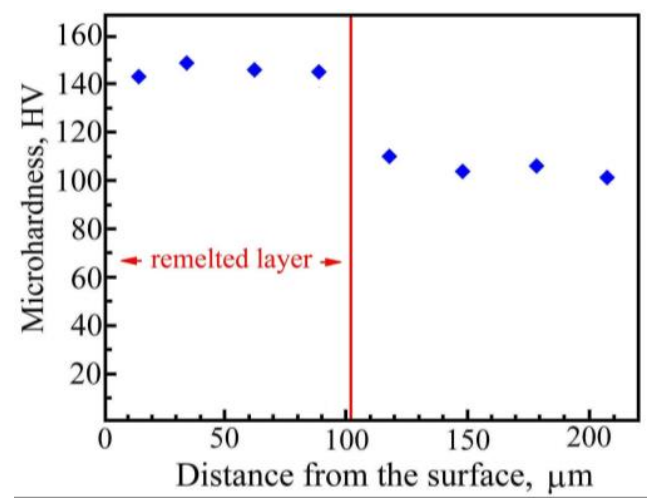

Fig. 4-Distribution of the microhardness values over the cross-section of D16AT aluminum alloy along the side affected by the electron beam

\section{STRENGTHENING MECHANISMS}

The hardness properties of metals and alloys responsible for the microhardness change are determined by a set of strengthening mechanisms. Regularly, the yield strength of aluminum alloys is described by the additive effect of various strengthening mechanisms [10-12]:

$$
\sigma_{0.2}=\sigma_{0}+\sigma_{G B}+\sigma_{s s}+\sigma_{d}+\sigma O r,(2)
$$

where $\sigma_{0}$ is the yield strength of pure aluminum (Peierls-Nabarro stress $\left.\sigma_{0}=10 \mathrm{MPa}\right), \sigma_{G B}$ is the yield strength change due to the grain boundary strengthening, $\sigma_{s s}$ is the yield strength change due to the aluminum-based solid solution concentration change, $\sigma_{d}$ is the impact on the strengthening due to the dislocation mechanisms, $\sigma_{O r}$ is the influence on strengthening due to the presence of secondary phase particles.

To recognize properly the nature of the strengthening processes when modifying the surface of D16AT aluminum alloy by an electron beam, we should perform impact analysis of strengthening mechanisms. Being aware of the reasons for the increase in the microhardness of the D16AT aluminum alloy surface layer, we can speak about the prospects for further hardening by irradiating the surface layer.

It is known that in polycrystalline materials, the conditional yield strength is related to the grain size, and the grain boundaries are effective barriers for moving dislocations. The finer the grains, the greater the extent of the boundaries and, consequently, the more often they occur along the path of moving dislocations. According to the Hall-Petch effect $[13,14]$, the impact of grain boundary hardening on the yield strength is defined as follows:

$$
\sigma_{G B}=K d^{-1 / 2},
$$

where $K=0.10 \mathrm{MPa} \times \mathrm{m}^{1 / 2}$ is the index of the grain boundary hardening of the Hall-Petch constant [15], $d$ is the average grain size. It is $30 \mathrm{MPa}$ for the initial structural state of D16AT aluminum alloy and it sharply increases to $112 \mathrm{MPa}$ for the modified layer.

A change in the alloying elements concentration in a solid solution can lead to solid-solution hardening. This type of hardening is caused by the interaction of moving dislocations with atoms of the distorted lattice and dissolved atoms causing distortion. Due to this mechanism, the obtained hardness value is kept under control mainly by the difference in sizes of dissolved and matrix atoms. Generally, $\sigma_{s s}$ can be expressed as [16]:

$$
\sigma_{\text {ss }}=\sigma_{\text {trace }}+\sum_{i} k_{i} C_{i}^{2 / 3},
$$

where $C_{i}$ is the concentration of the $i$-th alloying element, $k_{i}$ is the coefficient that determines the interaction of dislocations and the $i$-th alloying element.

$\mathrm{Mg}$ and $\mathrm{Cu}$ are the main alloying elements involved in solid solution hardening of D16AT aluminum alloy. Their values due to [17] are $k_{\mathrm{Mg}}=9.35 \mathrm{MPa} /(\text { wt. \%) })^{2 / 3}$ and $k_{\mathrm{Cu}}=15.0 \mathrm{MPa} /(\text { wt. } \%)^{2 / 3}$. The values provided by the averaged EDS for the as-cast alloy are the following: $C_{\mathrm{Mg}}=0.3$ wt. $\% \mathrm{Mg}$ and $C_{\mathrm{Cu}}=0.4$ wt. $\% \mathrm{Cu}$. And the values for the layer modified by the electron beam are $C_{\mathrm{Mg}}=0.9$ wt. $\% \mathrm{Mg}$ and $C_{\mathrm{Cu}}=3.1 \mathrm{wt} . \% \mathrm{Cu}$. Since D16AT aluminum alloy includes additional elements $\mathrm{Mn}, \mathrm{Fe}$, and $\mathrm{Si}$, we should consider the entry of these atoms into the solid solution as accumulated $\sigma_{\text {trace }}$, estimated at approximately $24 \mathrm{MPa}$ due to [18]. Therefore, $\sigma_{s s}$ for the as-cast alloy is $37 \mathrm{MPa}$, while for the irradiated layer it increases up to $65 \mathrm{MPa}$.

Dislocation hardening is caused by the interaction of dislocations during deformation. An increase in the dislocation density causes an increase in the interaction of dislocation and the stress required for the dislocation motion. The Taylor equation evaluates the effect of dislocation hardening as follows [13]:

$$
\sigma_{d}=M \alpha G b \sqrt{\rho},
$$

where $a$ is a dimensionless parameter approximately equal to 0.24 for aluminum alloys and which takes into account the distribution behavior and dislocation motion [12], $M$ is the Taylor factor considering the shear stress in a sliding system, which takes a value of 3.1 for aluminum alloys), $G$ is the shear modulus $(G=26 \mathrm{GPa}$ for aluminum alloys $), b(0.286 \mathrm{~nm})$ is the Burgers vector, $\rho$ is the dislocation density.

The value of $\sigma d$ for the as-cast alloy is $46 \mathrm{MPa}$ and $134 \mathrm{MPa}$ for the modified layer.

Dispersion hardening caused by the presence of secondary phase dispersion particles impeded the dislocation motion. The effect of dispersion hardening is expressed by the Orowan equation [10]:

$$
\sigma_{O r}=\frac{0,4 M G b}{\pi L \sqrt{1-v}} \ln \frac{D}{b},
$$

where $L$ is the effective distance between particles, $v$ is the Poisson's ratio, $D$ is the average particle diameter.

The effective distance between particles is measured as [19]:

$$
L=0,4155\left(\frac{F_{v}}{\pi r^{3}}\right)^{-1 / 3}
$$

where $F_{v}$ is the number of particles per unit volume, $r$ is the average particle radius.

The particles of $\theta$ - and $S$-phases present in the heat treatment process of cast semi-finished D16AT aluminum alloy affect mainly the dispersion hardening. The 
modified layer can affect the dispersion hardening performed by oxide particles arising during irradiation [2]. SEM shows $\sigma O r=203 \mathrm{MPa}$ for the initial D16AT alloy and $\sigma O r=131 \mathrm{MPa}$ for the modified layer.

\section{DISCUSSION}

If the microhardness is known, we can estimate the other mechanical properties. There are some methods for the approximate determination of the ultimate tensile strength and yield strength of a material based on microhardness data. According to [20], the Vickers microhardness value is equivalent to the true stress at $8 \%$ strain and can be expressed as:

$$
\sigma_{8}(\mathrm{MPa})=3,27 H V \text {. }
$$

For approximate calculations, the conditional yield strength of the material $\sigma 0.2$ is evaluated on the basis of $H V$ measurement according to the equation $\sigma_{0.2} \approx H V / 3$. Thus, the microhardness of as-cast D16AT aluminum alloy takes a value of $101 H V_{0.05}$ and should correspond to a $\sigma_{0.2}$ value of approximately $336 \mathrm{MPa}$. The microhardness of the modified layer is $147 H V_{0.05}$ and should correspond to a $\sigma_{0.2}$ value of approximately $490 \mathrm{MPa}$.

Table 2 shows the overall impact of the various hardening mechanisms of D16AT aluminum alloy that were evaluated on the basis of the obtained microstructure parameters. The calculated value of the conditional yield strength for the as-cast alloy (326 MPa) differs slightly from the value $\sigma_{0.2}=312 \mathrm{MPa}$ obtained in the simulation, as well as from the value $\sigma_{0.2}$ calculated from the microhardness data (336 MPa). The $\sigma_{0.2}$ value calculated on the basis of the microhardness data for the modified layer is equal to $490 \mathrm{MPa}$ and is slightly more than $\sigma_{0.2}$ obtained from the microstructure parameter data (454 $\mathrm{MPa})$. However, considering some difficulties in studying the modified layer microstructure, such tolerance is acceptable.

Thus, the calculated values of the effect of various strengthening mechanisms on the modified layer can help to recognize some structural and phase transformations upon irradiation of D16AT aluminum alloy with a pulsed electron beam. Table 2 shows that the $\sigma_{G B}, \sigma_{s s}$ and $\sigma_{d}$ values in the irradiation-modified layer increase. At the same time, one of the main reasons for the microhardness increase in the irradiated modified layer can be considered the dislocation strengthening mechanism. The $\sigma_{0 r}$ value for the irradiated surface is slightly reduced compared to the non-irradiated surface. However, the dispersion strengthening mechanism of the microhardness of the remelted layer remains significant. This is due to several factors. Despite the fact that most of the particles of the hardening phases dissolve upon irradiation, some of these phases remain in the modified layer due to the uneven temperature distribution in the alloy molten zone. Therefore, it is likely that some of the large particles of the hardening phases did not completely melt and dissolve. Also, during irradiation, the nucleation of aluminum and magnesium oxide particles is possible [2]. They will also affect the hardening of the modified layer. However, the effect of dispersion hardening on the modified layer hardness is significantly less than for the as-cast alloy.

Table 2 - Various impact mechanisms on the overall D16AT aluminum alloy hardening

\begin{tabular}{lllllll}
\hline & $\sigma 0$ & $\sigma_{G B}$ & $\sigma_{s s}$ & $\sigma_{d}$ & $\sigma_{O r}$ & $\sigma_{0.2}$ \\
& $\mathrm{MPa}$ & $\mathrm{MPa}$ & $\mathrm{MPa}$ & $\mathrm{MPa}$ & $\mathrm{MPa}$ & $\mathrm{MPa}$ \\
initial & 10 & 30 & 37 & 46 & 203 & 326 \\
modified & 10 & 112 & 65 & 134 & 131 & 452 \\
\hline
\end{tabular}

An important consequence of the performed calculations is the statement of the possibility to achieve better hardening values in the surface irradiated layer while keeping the core parameters of its microstructure unchanged due to the introduction of additional dislocation density. Cold rolling can increase the hardening value by $10-20 \%$ of the irradiated specimen. Thus, the application of intense pulsed electron beams along with cold rolling processing makes it difficult to obtain highly hardened surface coatings.

\section{CONCLUSIONS}

The D16AT aluminum alloy surface processed by a pulsed electron beam creates a surface layer with a thickness of $100 \mu \mathrm{m}$ along with a modified structure and phase states. The submicrocrystalline structure with an average grain size of $0.8 \mu \mathrm{m}$, an increase in the dislocation density and a decrease in the lattice parameter serve as the structural-phase state properties. The $\mathrm{Al}_{2} \mathrm{Cu}$ and $\mathrm{Al}_{2} \mathrm{CuMg}$ intermetallic phases available in the as-cast alloy are not detected by X-ray methods in the modified layer. The pulsed electron beam performs hardening of D16AT aluminum alloy with an increase in the layer microhardness over $50 \%$

To recognize properly the nature of the strengthening processes in the electron beam modified surface of D16AT aluminum alloy, we performed impact analysis of strengthening mechanisms. The as-cast alloy receives the basic impact due to dispersion strengthening mechanisms, and the modified irradiated layer receives the basic impact due to the dislocation motion and strengthening mechanisms. An additional dislocation density option, such as cold rolling processing, can continue improving the irradiated surface hardening.

\section{ACKNOWLEDGEMENTS}

The research presented in this article was performed with the financial support of the Ukrainian state budget program "Support for the development of priority areas of scientific research" (Budget Financial Code 6541230). 


\section{REFERENCES}

1. D.I. Proscurovsky, A.D. Pogrebnjak, phys. status solidi a 145 No 1, 9 (1994).

2. V.V. Bryukhovetsky, V.F. Klepikov, V.V. Lytvynenko, D.E. Myla, V.P. Poyda, A.V. Poyda, V.T. Uvarov, Yu.F. Lonin, A.G. Ponomarev, Nuclear Inst. Meth. Phys. Res. B 499, 25 (2021)

3. A.G. Kobets, P.R. Horodek, Yu.F. Lonin, V.V. Lytvynenko, A.G. Ponomarev, O.A. Startsev, V.T. Uvarov, Surface Eng. Appl. Electrochem. 51 No 5, 478 (2015).

4. R. Fetzer, G. Mueller, W. An, A. Weisenburger, Surface Coat. Technol. 258, 549 (2014).

5. Y. Hao, B. Gao, G.F. Tu, S.W. Li, C. Dong, Z.G. Zhang, Nuclear Inst. Meth. Phys. Res. B 269, 1499 (2011).

6. V.V. Bryukhovetsky, V.P. Pojda, A.V. Poyda, R.I. Kuznetsova, K.A. Mahmoud, D.E Pedun, Phys. Metal. Metallography 110 No 6, 588 (2010).

7. V.P. Poida, D.E. Pedun, V.V. Bryukhovetskii, A.V. Poida, R.V. Sukhov, A.L. Samsonik, V.V. Litvinenko, Phys. Metal. Metallography 114 No 9, 779 (2013).

8. A.D. Pogrebnjak, A.D. Mikhailov, N.A. Pogrebnjak, Yu.V. Tsvintarnaya, V.I. Lavrentiev, M. Iljashenko, A.N. Valyaev, S. Bratushka, A. Zecca, R. Sandrik, Phys. Lett. A 241, 357 (1998).
9. R.Z. Valiev, I.V. Alexandrov Nanostructured Materials Produced by Severe Plastic Deformation (Moscow: Logos: 2000).

10. L.M. Brown, R.K. Ham, Dislocation-particle Interactions. In Strengthening Methods in Crystals (Eds. A. Kelly, R.B. Nicholson) (Amsterdam: Elsevier: 1971).

11. L.F. Mondolfo, J.G. Barlcok, Metallurgical Trans. B 6, 565 (1975).

12. H. Asgharzadeh, A. Simchi, H.S. Kim, Mater. Sci. Eng. A 528, 3981 (2011).

13. N. Kamikawa, X. Huang, N. Tsuji, N. Hansen, Acta Mater. 57, 198 (2009)

14. N. Hansen, Scripta Mater. 51, 801 (2004)

15. G.E. Totten, D.S. MacKenzie. Handbook of Aluminium 1 (N.Y.: Marcel Dekker: 2003).

16. Ø. Ryen, O. Nijs, E. Sjolander, B. Holmedal, H.E. Ekstrom E. Nes, Metall. Mater. Trans. A 37, 1999 (2006).

17. H. Li, W. Xu, Z. Wang, B. Fang, R. Song, Z. Zheng, Mater. Sci. Eng. A 650, 254 (2016)

18. E.L. Huskins, B. Cao, K.T. Ramesh, Mater. Sci. Eng. A 527, $1292(2010)$

19. K.L. Kendig, D.B. Miracle, Acta Mater. 50, 4165 (2002).

20. D. Tabor, Phil. Mag. A 74 No 5, 1207 (1996).

\title{
Механізми зміцнення поверхневого шару дюралюмінію, модифікованого імпульсним релятивістським електронним сильнострумовим пучком
}

\author{
В.В. Брюховецький ${ }^{1}$, В.В. Литвиненко ${ }^{1}$, Д.Є. Мила ${ }^{1}$, Ю.Ф. Лонін ${ }^{2}$, А.Г. Пономарьов ${ }^{2}$, В.Т. Уваров ${ }^{2}$ \\ 1 Інститут електрофбізики і радіаційних технологій НАН України, вул. Чернишевська, 28, \\ a/c 8812, 61002 Харків, Україна \\ ${ }^{2}$ Національний науковий иентр "Харківський фбізики-технічний інститут» НАН Украӥни, вул. Акаделічна,
} 1, 61108 Харків, Украӥна

\begin{abstract}
Досліджено механізми зміцнення поверхневого шару алюмінієвого сплаву Д16АТ, опроміненого сильнострумовим релятивістським електронним пучком. Сплав опромінювали електронним пучком з енергією частинок $0,35 \mathrm{MeB}$, струмом пучка $2,0 \mathrm{kA}$ та тривалістю імпульсу 5 мкс. У статті показано, що обробка сильнострумовим релятивістським електронним пучком алюмініевого сплаву Д16АТ призводить до оплавлення опроміненої поверхні та утворення поверхневого шару з модифікованим стру ктурно-фазовим станом. Товщина шару складае приблизно 100 мкм. Основною фазою цього шару е твердий розчин на основі алюмінію, а інтерметалідні фази, які були присутні у вихідному стані спла ву, не виявляються методами рентгенівської дифрактометрії. Встановлено, що обробка поверхні сплаву Д16АТ імпульсним електронним пучком призводить до подрібнення зерна. У вихідному стані сплаву середній розмір зерен складае 11 мкм, а у модифікованому шарі середній розмір зерна складае приблизно 0,8 мкм. Мікротвердість опроміненого шару збільшуеться майже на 50 \%. Проаналізовано внесок різних механізмів зміцнення у зміну міцнісних характеристик модифікованого поверхневого шару. Показано, що для сплаву у вихідному стані основний внесок у зміцнення дае дисперсійний механізм, тоді як ключову роль у збільшенні мікротвердості модифікованого опроміненням шару відіграє дислокаційний механізм зміцнення. Обговорюеться значення цих спостережень для термомеханічної обробки алюмініевих сплавів з метою подальшого підвищення характеристик їх міцності.
\end{abstract}

Ключові слова: Сильнострумовий електронний пучок, Алюмінієвий сплав, Мікротвердість, Механізми зміщнення. 